تحليل شاخصهاى ارزيابى راندمان در جويجههاى با شرايط نفوذ تجمعى يكنواخت و متغير

فرزاد حقنظرى'، مهشيد قنبريان علويجه"”، على شينى دشتخل " و سعيد برومند نسب

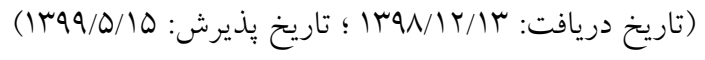

جكيده

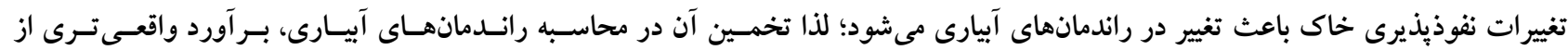

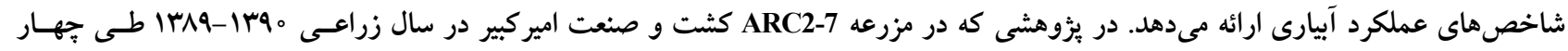

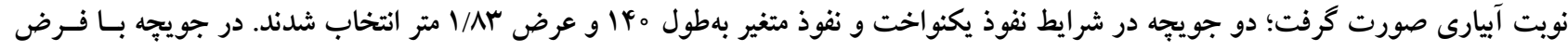

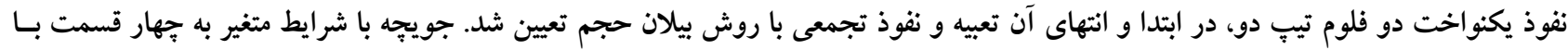

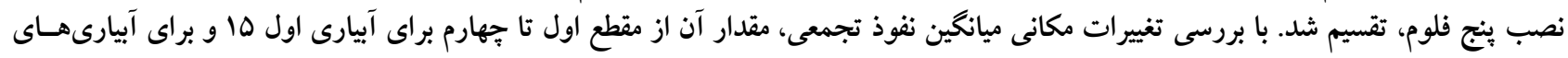

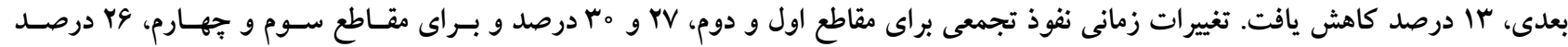

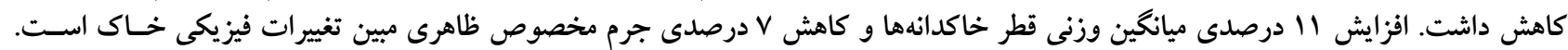

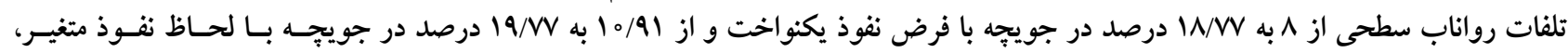

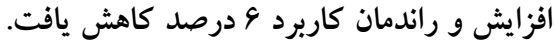

وازمهاى كليدى: آبيارى جويجهاى، راندمان كاربرد، نفوذيذيرى، تغييرات نفوذ.

ا كروه آبيارى و زهكشى، دانشگاه آب و خاك، دانشخاه زابل r. گروه مهندسى آب، دانشكده كشاورزى، دانشخاه صنعتى اصفهان

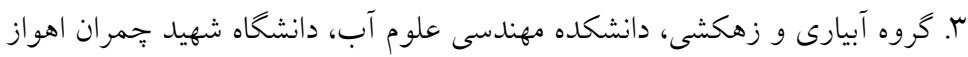
* * مسئول مكاتبات: يست الكترونيكى: m.ghanbarian@ag.iut.ac.ir 
نفوذ بين دو منطقة متفاوت، به بافت خـاك بسـتخى دارد؛ امـا

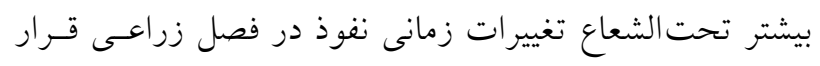

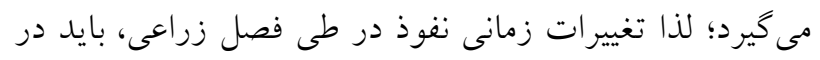

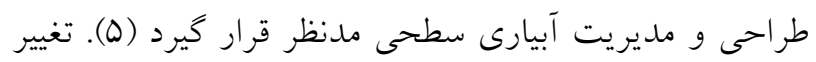

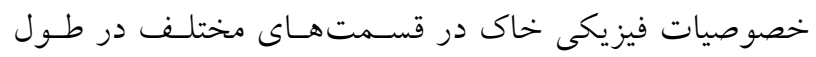
جويجهه طى فصل رشد باعث ايجاد تغييـر در مقــار نفـوذ در

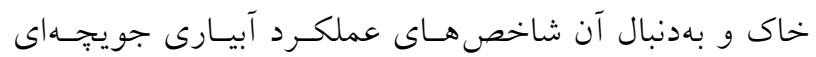

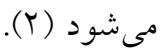
اغلب در آبيـارىهـاى اول ابتـداى فصـل زراعسى، بـهدليـل تغييـرات وسـيع مقــار نفـوذ تجمعسى، يـيشبينـى كـارايى و

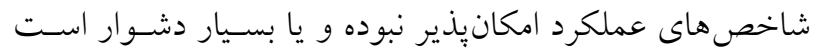
(0). استفاده از متوسط تغييرات زمانى نفـوذ، مسىتوانـد سـبب

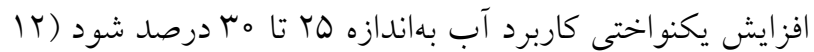
و ه1). طبق نتايج يزوهشى كه تغييرات مكانى و زمانى ضـرايب نفوذ معادله كاسـتياكوف - لـوييس در آبيـارى جويجزهـاى مـورد بررسى قرار كرفـ؛ ضـرايب نفـوذ از لحـاظ مكـانى و زمـانى تغييرات نامنظمى دارند و بــراى تعيـين دقيـقتـر بــازده كـاربرد

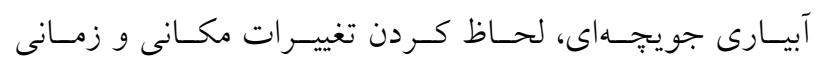

$$
\text { خصوصيات نفوذ، ضرورى است (II). }
$$
در اغلب مطالعات مربوط به نفوذ و نفوذيـذيرى در شـرايط

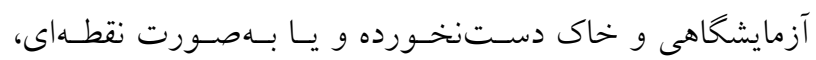
توسط استوانههاى مضاعف و در شرايط بدون گياه انجام شده و

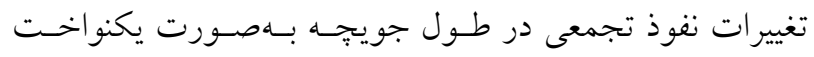
درنظر كرفته شده است. در بزّوهش حاضـر، تغييـرات نفـوذ در مزرعه و در حضور كياه صورت كرفت. نفـوذ آب در خــاك در طول جويجهه با شـرايط متغيـر انـدازهذيـرى شــه و بــا شـرايط يكنواخت مقايسه شد. درنهايت اثـر تغييـرات نفـوذ تجمعسى در طول جويجهه بر راندمان كـاربرد، تلفـات عمقىى آب و روانـاب سطحى مورد ارزيابى قـرار كرفتـ. بـا اينكـهـ نتـايج در حالـت كلىترى بررسى شدهاند؛ در اين يزوهش نمىتوان اثرات نيشكر را ناديده گرفت؛ بـى شك عمق توسعه ريشه، بر اكندگى ريشه و.. در تغييرات نفوذ تأثير گذارند.

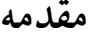

نفوذ، حساسترين و اغلب مشكلترين پِارامتر براى ارزيـابى در

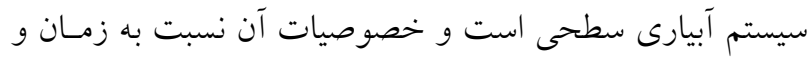

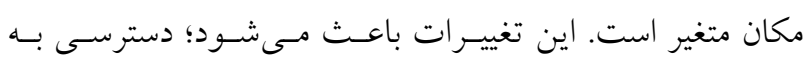

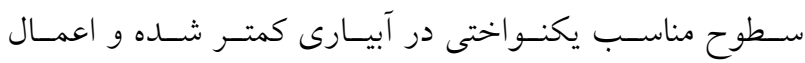

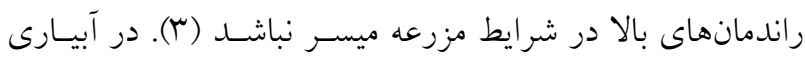

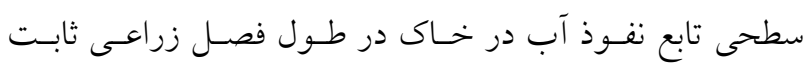

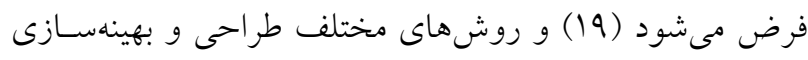

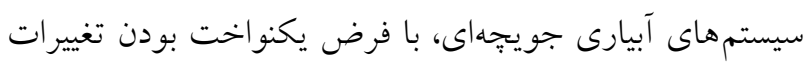

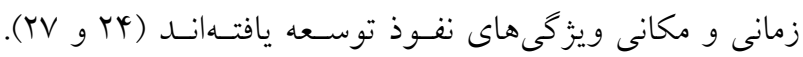

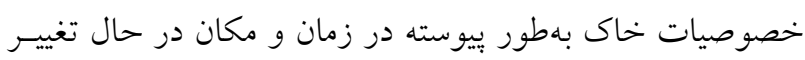

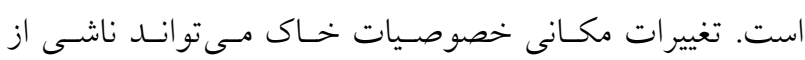

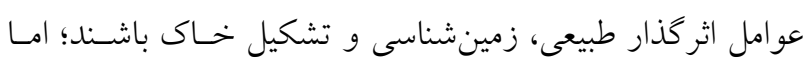
برخى از اين تغييرات ناشى از عوامل مديريتى است (1)). نفـوذ

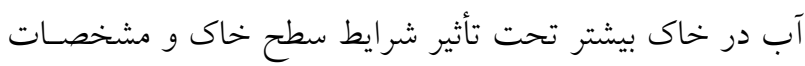

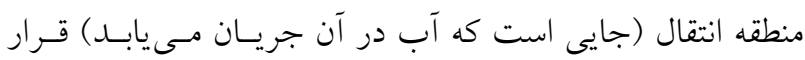

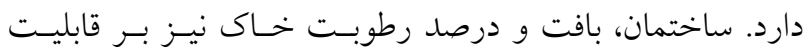

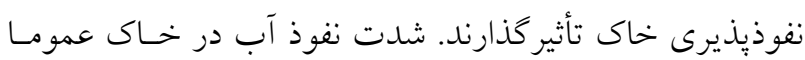

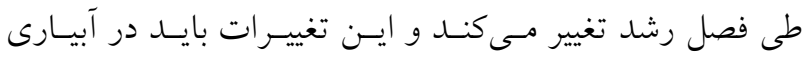

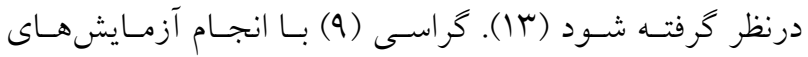

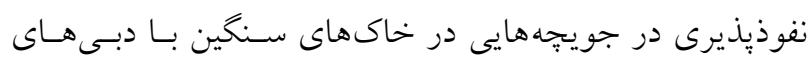
ورودى مختلف، ملاحظه كرد در جويجهها مقدار نفوذ بـه دبسى جريان ورودى نيز بستخى دارد.

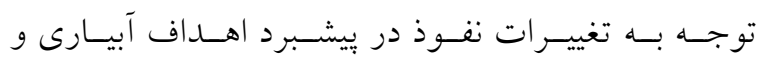

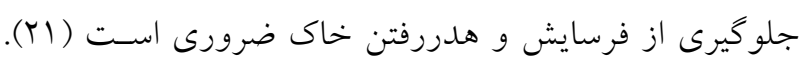

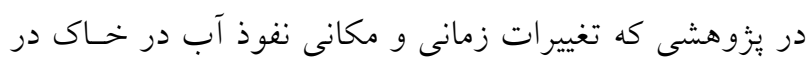
مزارع آبيارى شده با جريانهاى سـيلابى، مـورد مطالعـه قـرار

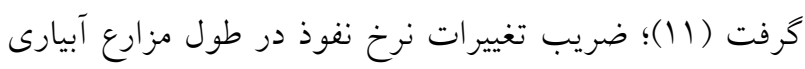

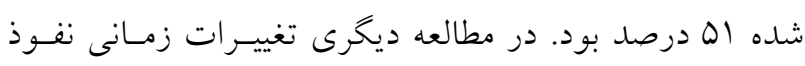

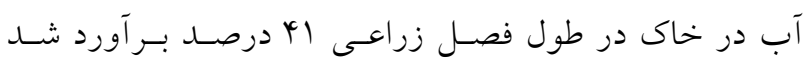

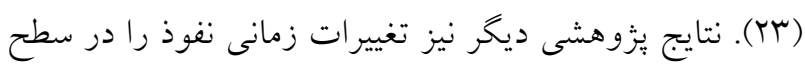

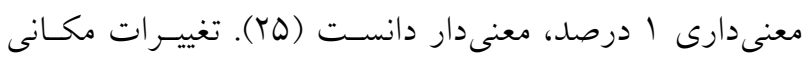


(ميانخين قطر سوراخهاى الك بالايى و بِايينى)، n: تعداد الكهــا و

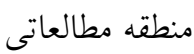

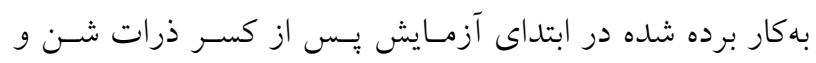

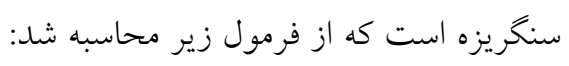

$\mathrm{W}_{\mathrm{i}}=\frac{\mathrm{W}_{\mathrm{i}}-\mathrm{W}_{\mathrm{i}(\mathrm{s})}}{\mathrm{W}_{\mathrm{t}}-\sum_{\mathrm{i}=1}^{\mathrm{n}} \mathrm{W}_{\mathrm{i}(\mathrm{s})}}$

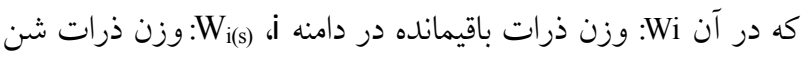

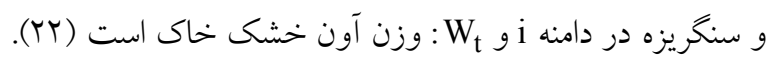

\section{روش اجرا و جانمايى طرح}

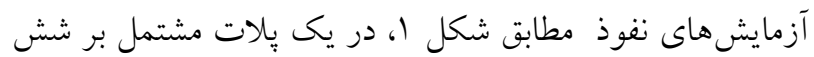

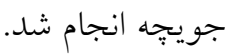
از آنجا كه در نقوذ آب به داخل خلاك بيشتر حركت عمـودى آب به داخل خاك مورد نظر است؛ استفاده از جويجه حائل بـراى

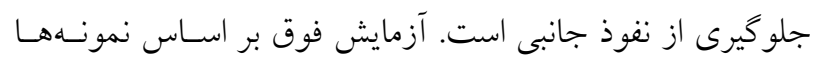

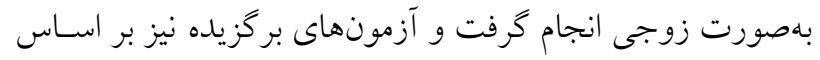

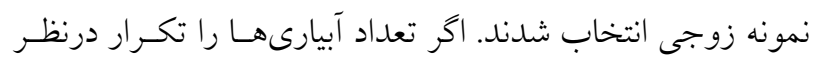

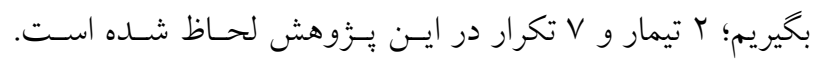

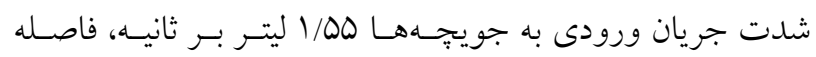

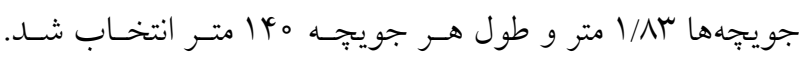

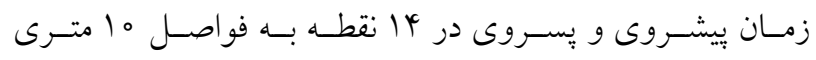

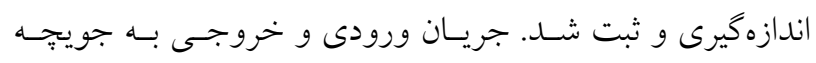

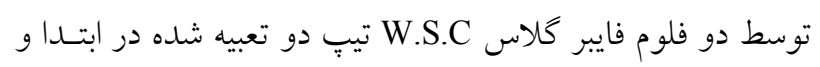

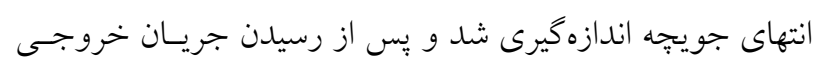

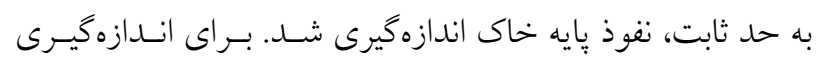

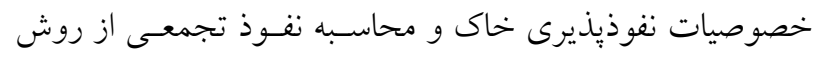

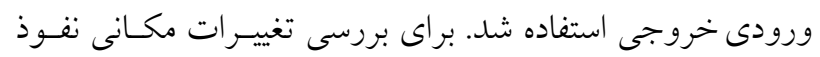

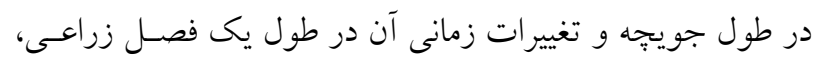

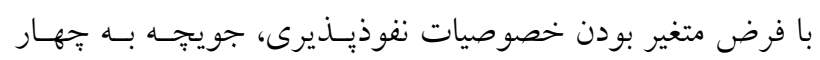

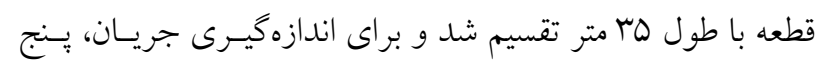

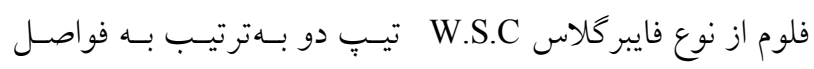

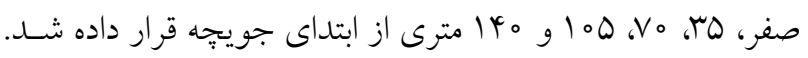

\section{تعيين ميانگين وزنى قطر خاكدانهها}

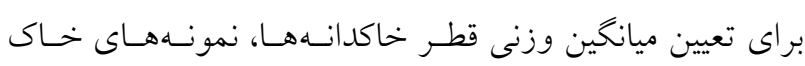

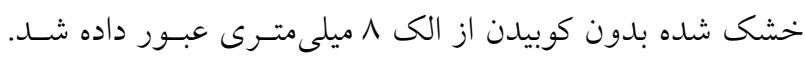

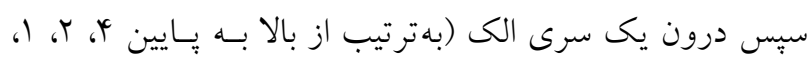

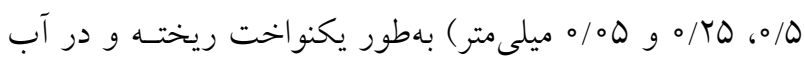
تكان داده شد. خاكدانههاى باقيمانده روى هر الكى شسته شده و

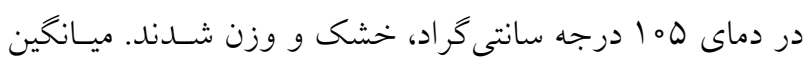

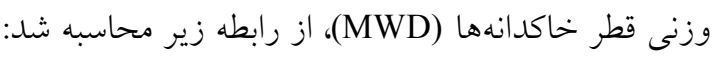
$\mathrm{MWD}=\sum_{\mathrm{i}=1}^{\mathrm{n}} \overline{\mathrm{x}_{\mathrm{i}}} \mathrm{w}_{\mathrm{i}}$

كه در آن 
جدول ا. برخى خصوصيات فيزيكى خاك قبل از آبيارى

\begin{tabular}{|c|c|c|c|c|}
\hline $\begin{array}{l}\text { FC-PWP } \\
\text { ( حجمى () }\end{array}$ & $\begin{array}{c}\text { PWP } \\
\text { ( حجمى\%) }\end{array}$ & $\begin{array}{c}\mathrm{FC} \\
\left(\begin{array}{c}\% \\
(\%)\end{array}\right)\end{array}$ & جرم مخصوص ظاهرى قبل از آبيارى & $\begin{array}{c}\text { عمق خاك } \\
\text { (cm) }\end{array}$ \\
\hline$|V /|$ & $\mid N / \uparrow \Lambda$ & $\Gamma \Delta / \Delta \wedge$ & $1 / 91$ & سז-0 \\
\hline $11 / v 9$ & $1 \pi / \Delta \Delta$ & rQ/ & $1 / 00$ & r-9q \\
\hline$|Y / Y|$ & Q/Vq & $r \mu / q V$ & $1 / D Y$ & $99-100$ \\
\hline
\end{tabular}

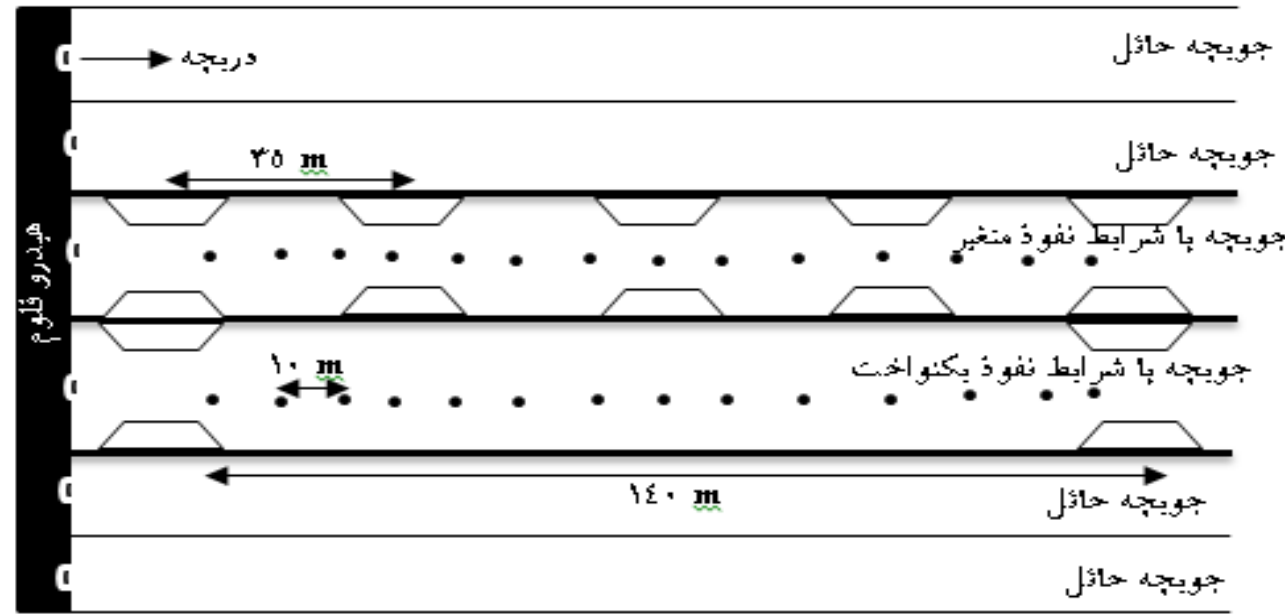

شكل 1. جانمايى طرح

از آب داده شده كه بهصورت رواناب از انتهـاى مزرعـه خـارج

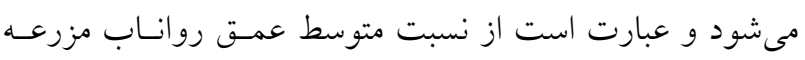
به متوسط عمق آب بهكار برده شده (D)

$\mathrm{TWR}=\frac{\mathrm{D}_{\mathrm{R}}}{\mathrm{D}_{\mathrm{Z}}}$

نسبت نفوذ عمقى Deep Percolation Ratio) DPR): آن قسمت از آب داده شده است كه بهصورت تلفات عمقى از انتهاى ناحيـه ريشه خارج مىشود و عبارت است از نسبت متوسط عمـق نفـوذ

عمقى (DP) به متوسط عمق آب به كار برده شده (D): $\mathrm{DPR}=\frac{\mathrm{D}_{\mathrm{R}}}{\mathrm{D}_{\mathrm{Z}}}$

راندمان كاربرد آب Application Efficiency) Ea): درصدى از آب داده شده كه در ناحيه ريشه براى استفاده بعدى گياه ذخيـره شده است؛ را بيان مى كند و عبارت است از نسبت متوسط عمق

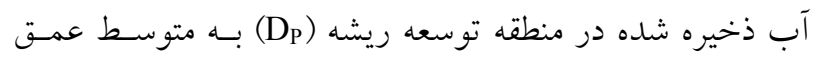
آب بهكار برده شده در مزرعه (D):
شدت جريان ورودىى به قطعات بهوسيله فلوم بالادست و شــت جريان خروجى از آنها، با فلوم باييندست هر كـدام انـدازهذيـرى به شد. اندازهيرى جريان در فلومها بر مبناى سنجش عمـق جريـان در آنها صورت كرفت. با استفاده از هيدروگراف هاى جريانهـاى ورودى و خروجى، مقادير حجم كاربردى، حجم رواناب متوسط، ميزان نفوذ آب هر جويجيه و متوسط نفوذ آب بـراى هـر آبيـارى

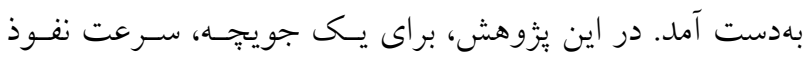
نهايى در كل طـول جويجيـه يكسـان درنظـر كرفتـه شـد؛ امـا در جويجه، با شرايط نفوذيذيرى متغير، فرض شد كه سرعت نفوذ در طول جويجهه مىتواند؛ دستخوش تغييرات شود و موجب خطا در اندازهيرى و محاسبات و درنهايت موجب تغيير در راندمانهـاى اندازه كيرى شود.

شاخص هاى ارزيابى راندمان نسبت رواناب سطحى Tail Water Ratio) TWR): آن قسـمت 
r اختلاف ميانخين ها درحدود هـ ه / است، آزمون ايسن مقـدار تغيير را معنى دار تشخيص نمىدهد.

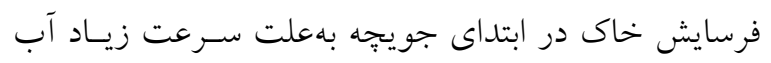

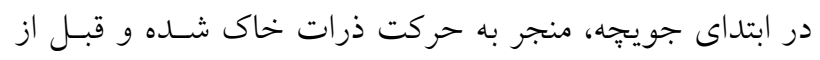

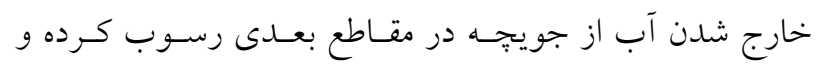

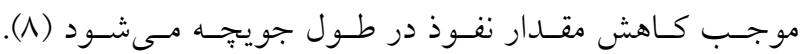

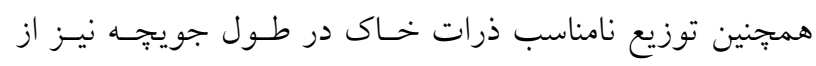

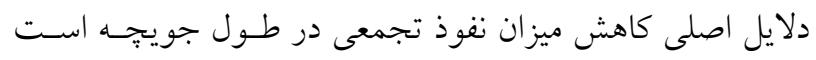

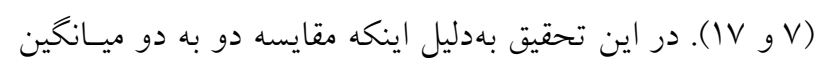

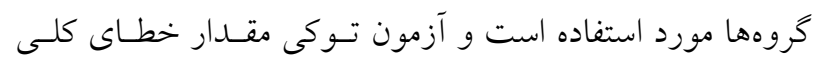

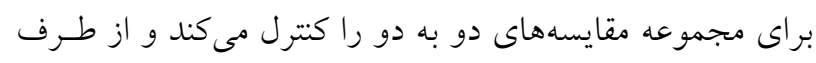

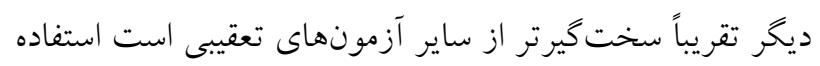
از اين روش مناسبتر است (1)

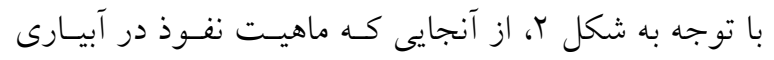

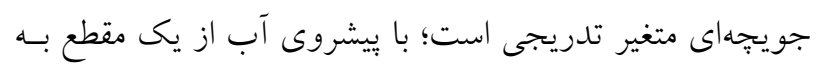

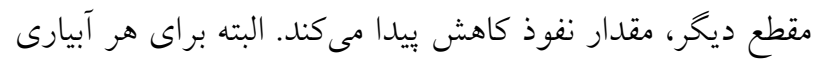

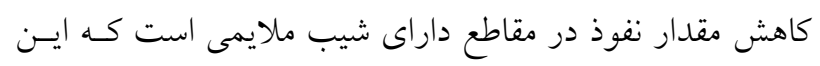

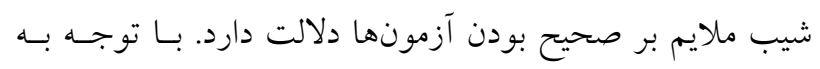

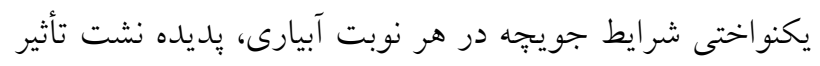

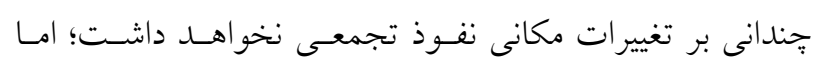

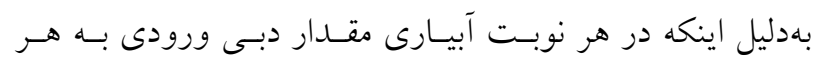

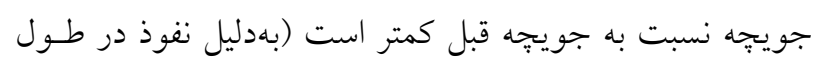
جويجهة) درنتيجه حجم آب كمترى به مقطع بعدى وارد مى نشود

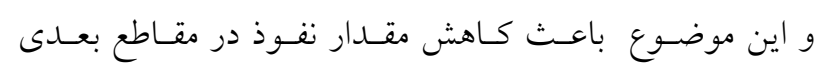

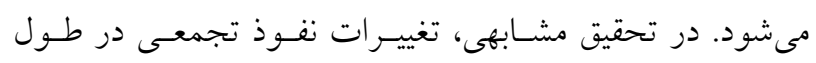

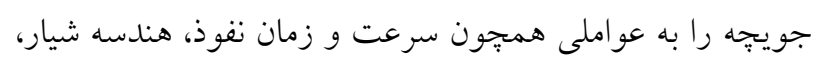
شيب مزرعه و تغييرات شيار نسبت مىدهد (Y) (ب).

\section{تغييرات زمانى نفوذ تجمعى در جويجه با شرايط نفوذ متغير}

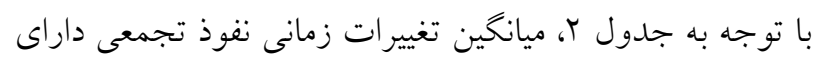

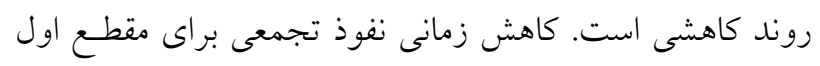

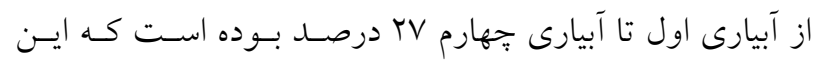

$E_{a}=\frac{D_{d}}{D_{z}}$

توزيـع يكنــواختى Distribution Uniformity) DU): عبـارت است از نسبت متوسط عمق نفوذ در يك جهارم كمترين مقــادير

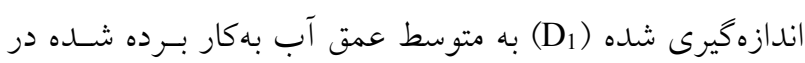
مزرعه (i (

$$
\mathrm{DU}=\frac{\mathrm{D}_{1}}{\mathrm{D}_{\mathrm{Z}}} \times 100
$$

\section{نتايج و بحث}

تغييرات مكانى و زمانى نفوذ تجمعى در جويجه بـا شــرايط نفوذ متغير

درآزمايش نفوذيذيرى به روش ورودى -خروجى بـا نصـب وسـيله

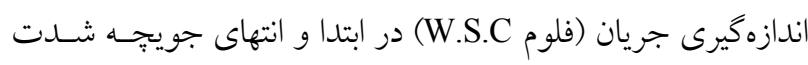

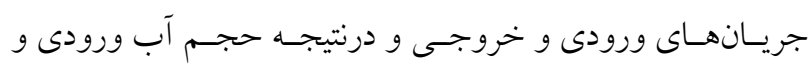
خروجى اندازهيرى و با محاسبه حجم آب ذخيره سطحى و وحجم ورنم

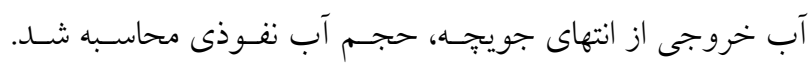

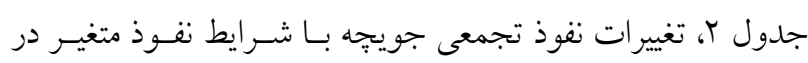
قطعهاى مختلف براى هر دور آبيارى را نشان مى دهد.

تغييرات مكانى نفوذ تجمعى در جويجه با شرايط نفوذ متغير

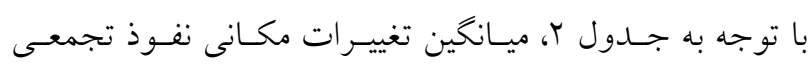

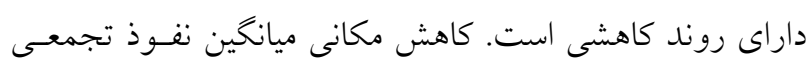

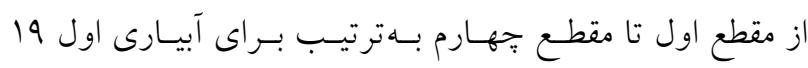

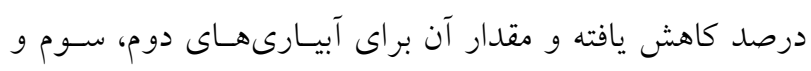

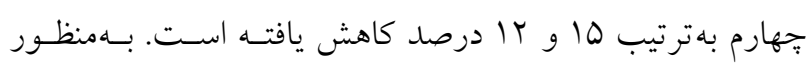
بررسى آمارى تغييرات مكانى نفوذ تجمعى از تحليـل واريـانس

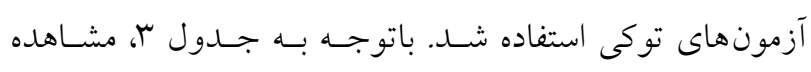

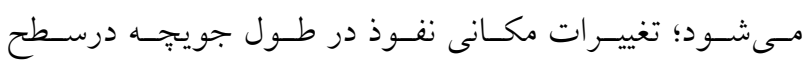

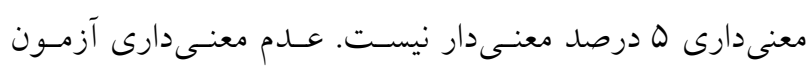

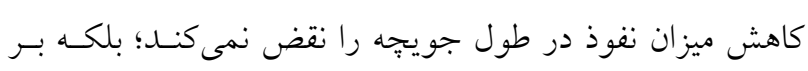

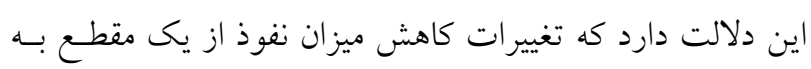

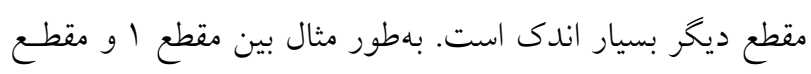


جدول r. تغييرات نفوذ تجمعى جويجه با شرايط نفوذ متغير در قطعهاى مختلف براى هر دور آبيارى

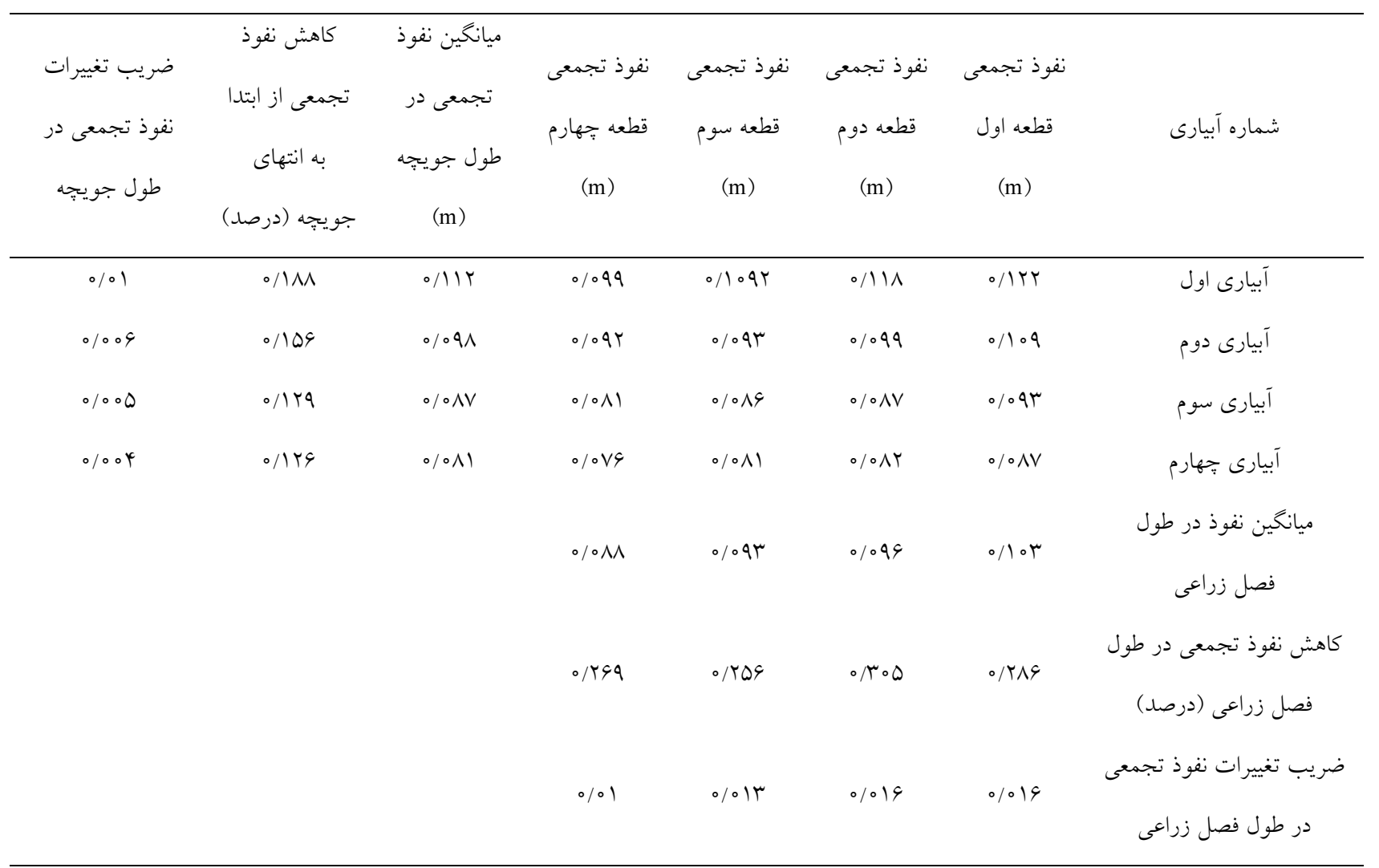

جدول r. بررسى تغييرات مكانى نفوذ با آزمون توكى

\begin{tabular}{|c|c|c|c|c|}
\hline سطح معنى دارى & اختلاف ميانگين (Y-1) & مقطع (Y) & مقطع (1) & آز آزمون \\
\hline $0 / 94 \wedge$ & \%००DHG & r & & \multirow{12}{*}{ Tukey HSD } \\
\hline o/Ar & \%OONYT & r & 1 & \\
\hline - &.$/ 011 \mathrm{Vq}$ & 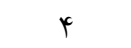 & & \\
\hline.$/ 94 \wedge$ & $-\circ / 0 \circ \Delta K$ & 1 & & \\
\hline $0 / 991$ & ०/O० TAG & r & r & \\
\hline ०/AMI & ०/००Nkr & q & & \\
\hline o/Ar & $-0 / 0 \circ \wedge r$ & 1 & & \\
\hline.$/ 991$ & - ०/०० Yq & r & r & \\
\hline O/9KY & ०/००DQ & $\varphi$ & & \\
\hline - & $-0 / 01 \% \wedge$ & 1 & & \\
\hline ०/AMI & $-0 / 0 \circ \wedge k$ & r & $\varphi$ & \\
\hline o/9KY & $-\circ / \circ \circ \Delta Y$ & r & & \\
\hline
\end{tabular}




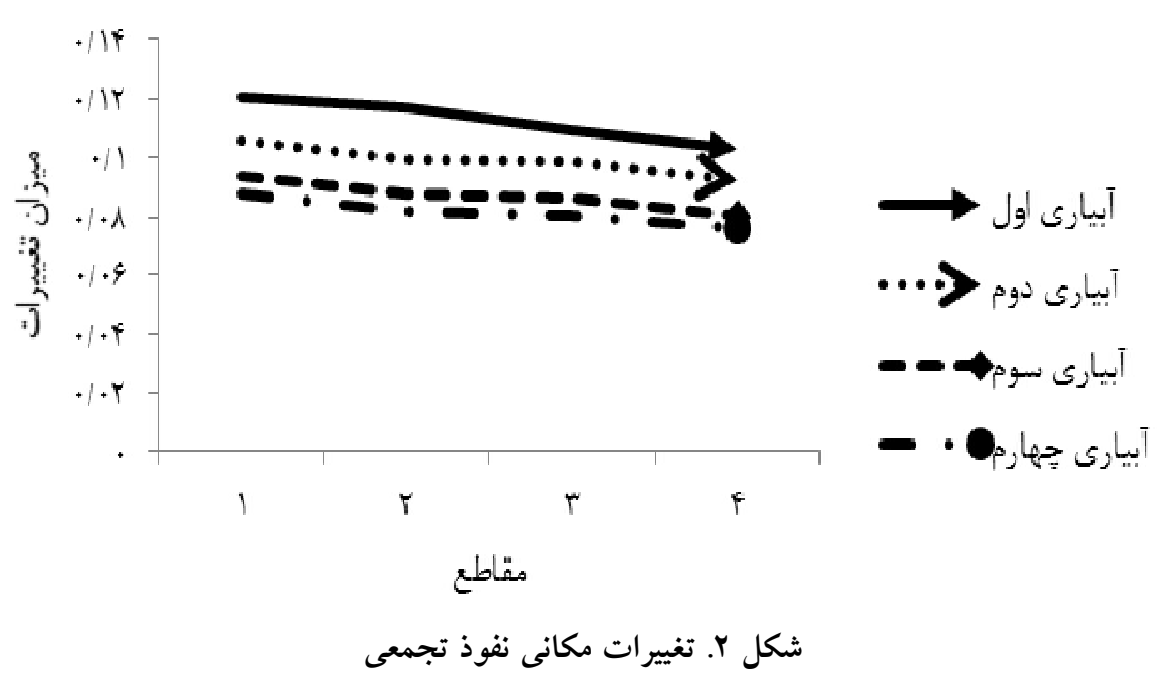

جدول Y. تست نمونههاى زوجى براى سنجش تغييرات زمانى نفوذ

\begin{tabular}{|c|c|c|c|c|c|c|}
\hline \multirow[b]{2}{*}{ سطح معنى دارى } & \multirow[b]{2}{*}{ درجه آزادى } & \multirow[b]{2}{*}{ شاخص t } & \multicolumn{2}{|c|}{ اختلاف زوجها } & \multirow[b]{2}{*}{ مقاطع } & \multirow[b]{2}{*}{ زوجها } \\
\hline & & & انحراف معيار & ميانكين & & \\
\hline $0 / 004$ & r & V/av^ & \%००/MATAM & \%००DTQAVD & مقطع 1 - مقطع ' & زوج \\
\hline$\% \circ \circ \Delta$ & $r$ & V/DKT & $\% / 00 Y \mid \Lambda .901$ & \%ONYYKYD & مقطع 1 - مقطعَّ & زوج r \\
\hline $0 / 001$ & r & $11 / r \Delta q$ & \%OFKTVGQF & o/OIVVNVQ & مقطع 1 - مقطع ' & زوج r \\
\hline $.0 \% 99$ & r & $1 / 90 V$ & \%OHYOVOAY & \%OYMGYA & مقطع ب - مقطع r & زوج \\
\hline $0 / 019$ & $r$ & Y/GKY & \%orgmitor & \%OANTVWD & مقطع Y - مقطع Y & زوج ه \\
\hline$\circ$ & $r$ & $r r / \circ 9 \Lambda$ & $\circ / \circ \circ \% \forall I V \circ \Lambda$ & \%ODDGTYD & مقطع r - مقطع ب & زوج 4 \\
\hline
\end{tabular}

يُزوهش ها كاهش مقــدار نفـوذ يـس از آبيـارى اول را بـهدليـل مسدود شدن منافذ خاك با ذرات كل و لاى بيان كـردهانــ (r). از طرفى سلهبستن خاك بهدليل تخريب ساختمان خاك سطحى

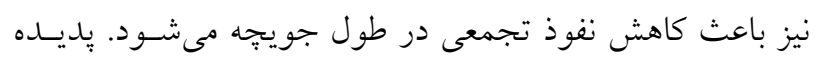

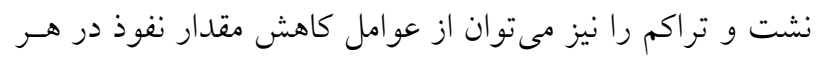

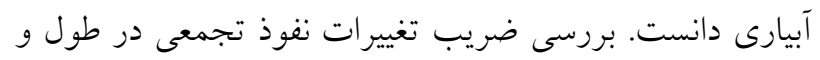

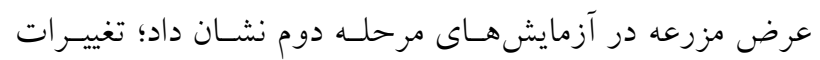

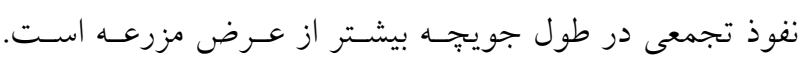

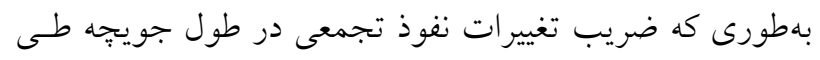

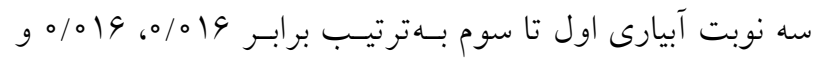

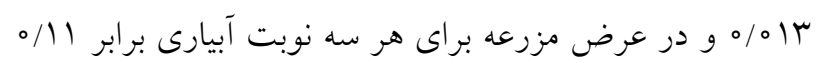

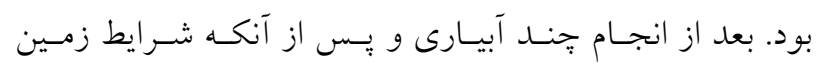

روند براى مقطع دوم مب درصد و براى مقاطع سوم و جهارم از

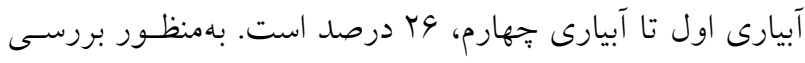

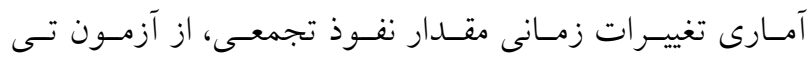
استيودنت استفاده شد (جدول \&). با توجه به جدول ه، تغييرات زمانى مقدار نفوذ در سطح معنى دارى ه درصــ معنسى دار شـد.

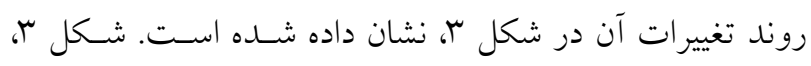

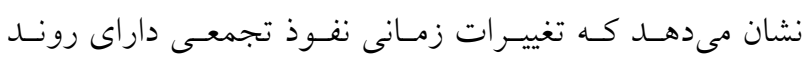

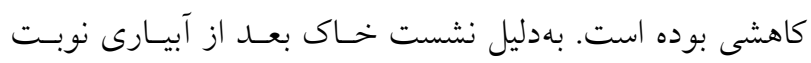

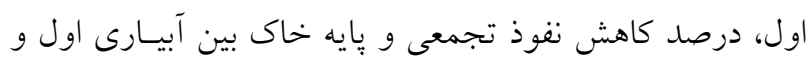

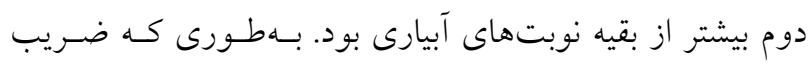

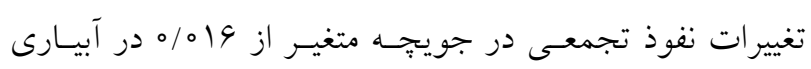

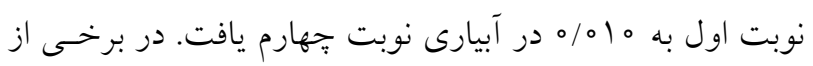


جدول ه. شاخص هاى ارزيابى راندمان

\begin{tabular}{|c|c|c|c|c|c|c|c|c|}
\hline \multicolumn{4}{|c|}{ شاخص هاى ارزيابى جويجֶه يكسان } & \multicolumn{4}{|c|}{ شاخصهاى ارزيابى جويجٍه متغير } & \multirow{2}{*}{ 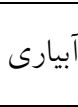 } \\
\hline TWR \% & DPR\% & EA\% & DU\% & TWR \% & DPR \% & EA\% & DU\% & \\
\hline$\wedge$ & r & OY & $V T / v q$ & $10 / 91$ & rq & Q. & 91 & 1 \\
\hline$I V / F Y$ & $r y / \circ{ }^{2}$ & $\varphi V / D$ & $V \pi / \wedge q$ & $14 / 0 r$ & $K T / Q V$ & r & 99 & r \\
\hline $1 Y / 9 V$ & TG/9V & $\Delta \wedge$ & $V \pi / 9 \Lambda$ & $|V / 9|$ & $T V / T V$ & $\Delta \Delta$ & 99 & r \\
\hline IN/VV & $r / / \Lambda$ & 90 & $V r / 9 \wedge r$ & $19 / \mathrm{VV}$ & $T Y / \Lambda Y$ & $\Delta \wedge$ & VI & y \\
\hline
\end{tabular}

$* \mathrm{TWR}=\frac{\mathrm{D}_{\mathrm{R}}}{\mathrm{D}_{\mathrm{z}}}, * * \mathrm{DPR}=\frac{\mathrm{D}_{\mathrm{P}}}{\mathrm{D}_{\mathrm{z}}}, * * * \mathrm{E}_{\mathrm{a}}=\frac{\mathrm{D}_{\mathrm{d}}}{\mathrm{D}_{\mathrm{z}}}$

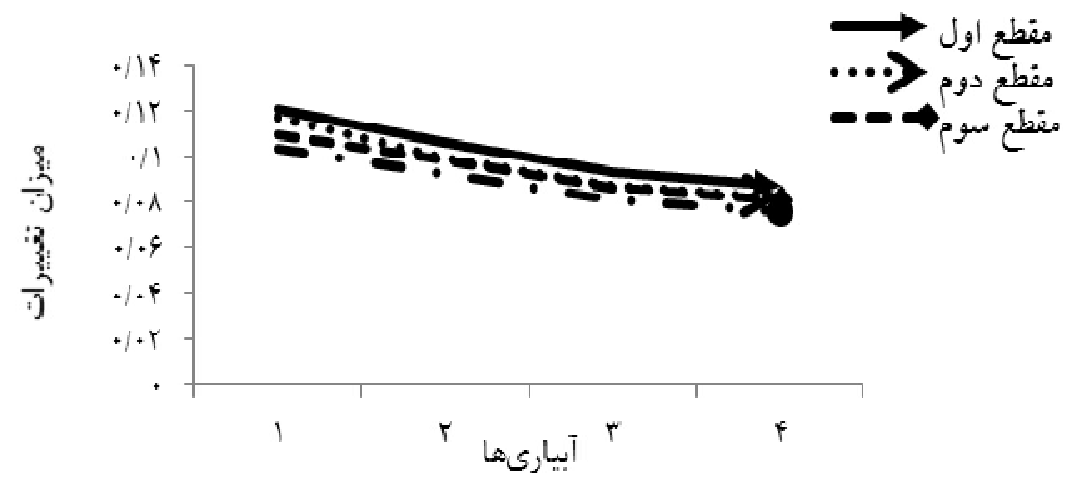

شكل r. تغييرات زمانى نفوذ تجمعى در هر مقطع

خشك باهعلت محبوس شدن هوا، سبب متلاشى شدن خاكدانهها و افزايش فرسايش مىشود. خيس شدن سريع در جويجهها، يكى از عوامل مهم تخريب خاكدانهها و كاهش نفوذ است.

ارزيابى شاخص هاى راندمان در جويجههاى با شرايط نفـوذ يكنو اخت و متغير تنايج محاسبه شاخص هاى ارزيابى جويجزهـهـا كـه شـامل توزيـع يكنـو اختى (DU)، رانــدمان كـاربرد (AE)، نسـبت نفـوذ عمقسى و نسبت رواناب سطحى براى دوجويجهه با شـر ايط نفـوذ تجمعى متغير و يكنواخت بـوده در جــدول ها ارائسه شـده اسـت. نتايج نشان داد كه يكنواختى توزيع در جويجهه متغير براى آبيـارى نوبت اول برابر اودرصد بوده و مقدار آن در جويجنه يكنواخـت برابر با VY/V9 درصد، همجنين مقادير راندمان كاربرد، نسبت نفوذ عمقى و نسبت رواناب سطحى براى آبيارى اول در جويجهه متغير
يايدارتر شد، تغييرات نقوذيذيرى كاهش يافته و اين امر معمـولاً در نيمـهـ دوم آبيـارىهـا اتفـاق مسى افتـــ و ايـن كـاهش در تغيــرات

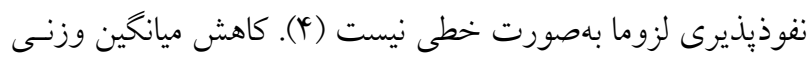

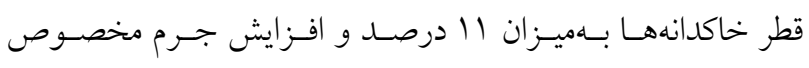

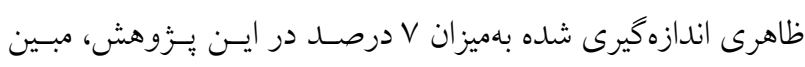
تخريب لايه سطحى خاك و تغييرات فيزيكى در نتيجسه تمـاس و برخورد آب با خاى است. فشردگى خاك از عوامل مؤثر بر كـاهش نفوذيذيرى در خلال يك فصـل زراعسى اسـت كـه باعـث كـاهش يارامتر نقوذيذيرى نهايى خاى (fo) مىشود (9) (1). اندازهيـرىهـاى نفوذ نهايى خـاك (f) نشـان داد؛ رونـــ تغييـرات نفـوذ نهـايى نيـز

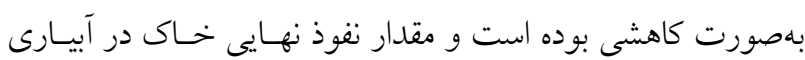
جهارم بهميزان ه r درصد نسبت بـه آبيـارى اول كـاهش يافـت كـهـ درنهايت موجب كاهش ميـزان نفـوذ تجمعى شـــ. يـزوهش هــاى مختلف (و، ب و و Y ) نشان داد كه خيسشدكى سـريع خـاكهـاى 
اين امر بهنوبه خود تخمين راندمانهاى آبيارى را بـا مقـدارى

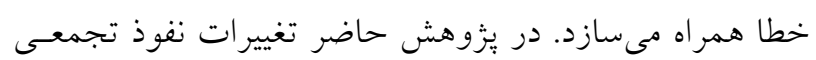

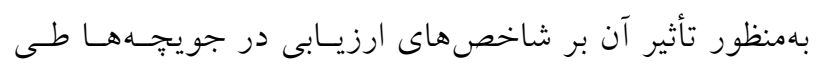

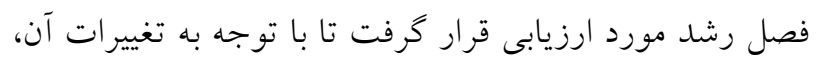

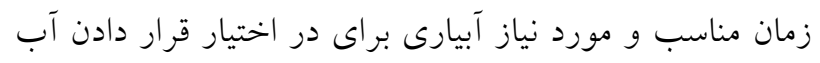

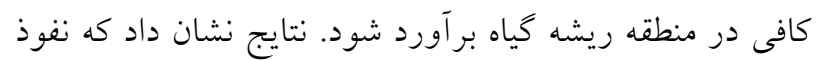
تجمعى خاك نسبت به زمان و مكان روندى كاهشى را دنبـ دنسال مى كند. در ضمن درصد كاهش نفوذ تجمعى بين آبيارى اول و

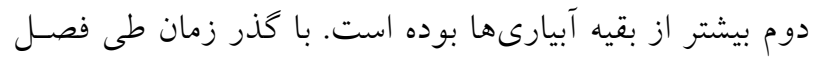

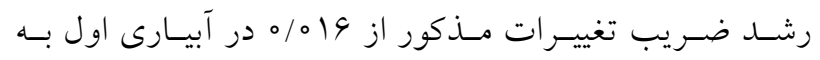

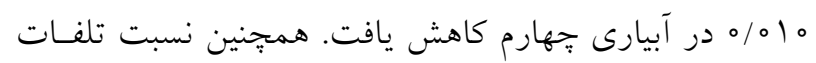

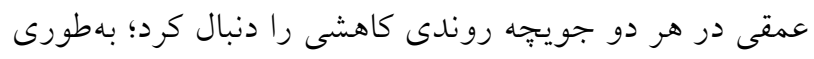

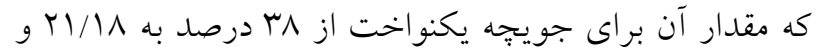

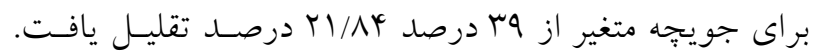
نتايج بهدست آمده از اين يُزوهش بيانكر آن است كه تغييرات

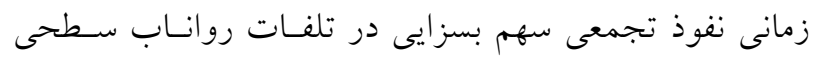

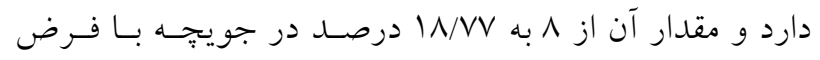

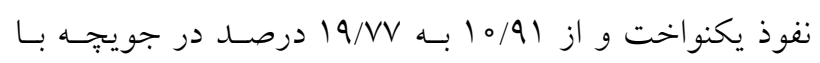

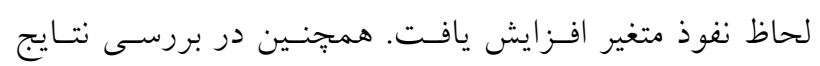

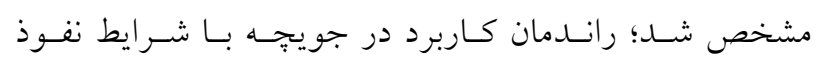

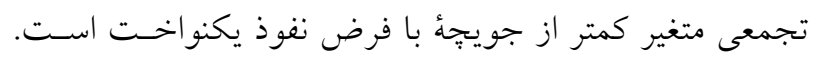

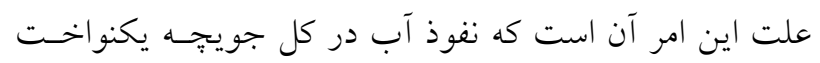

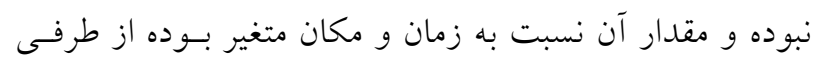

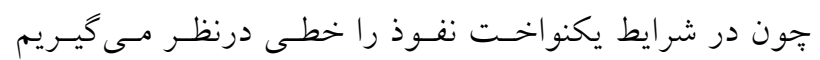

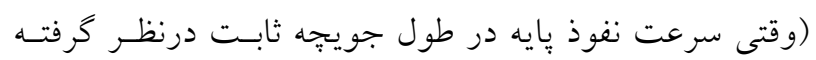

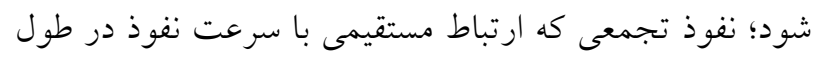

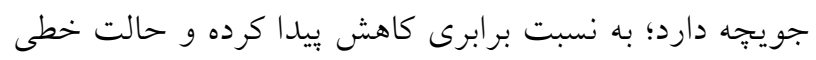

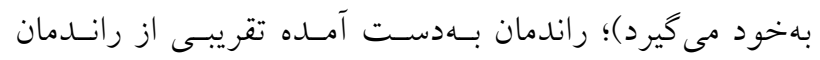

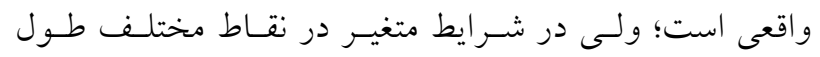

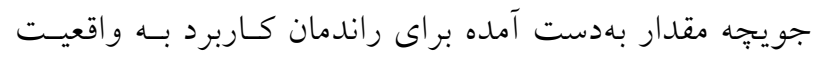

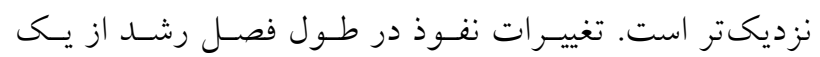

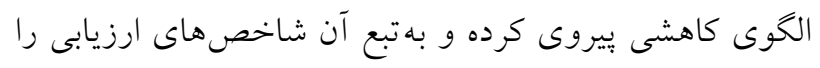

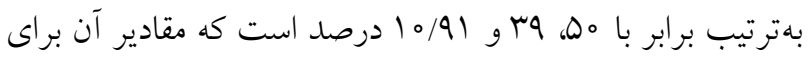

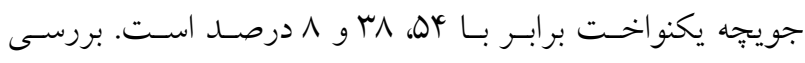

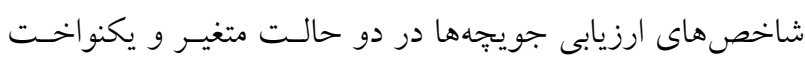

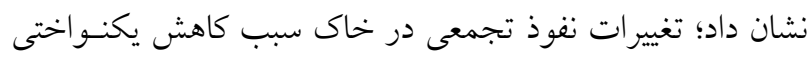

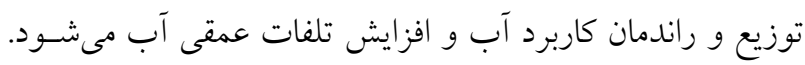

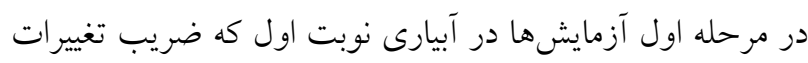

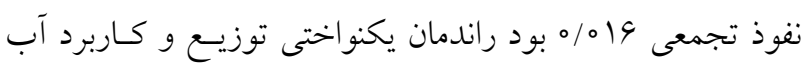

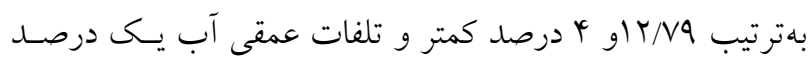

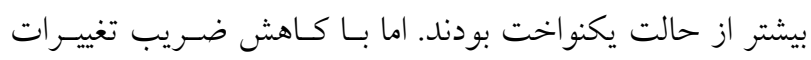

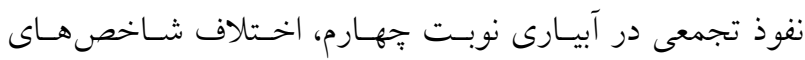

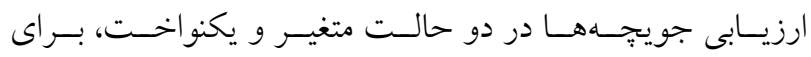

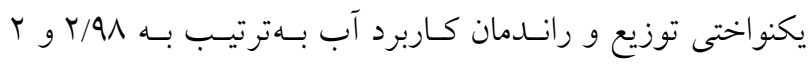

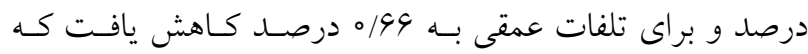

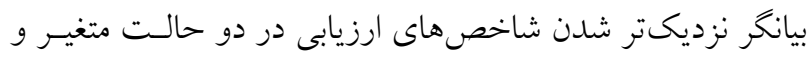
يكنواخت است. وقتى در شـرايط خـاك مرطسوب آبيـارى انجـام

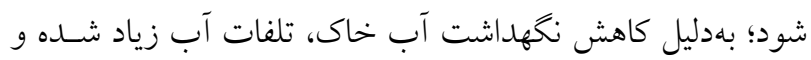

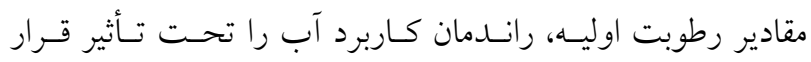

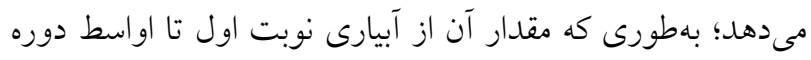

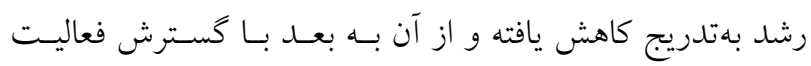

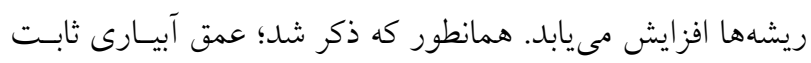

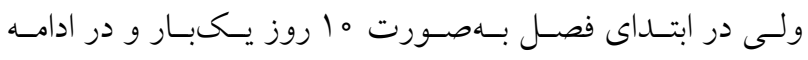

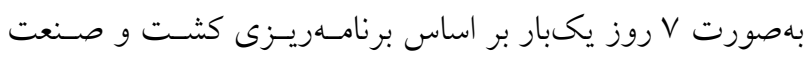

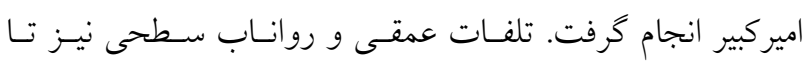

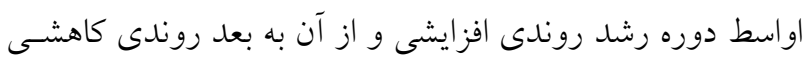

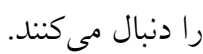

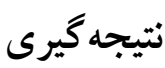

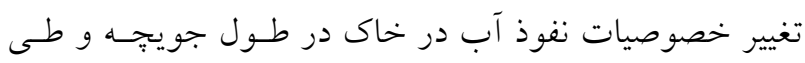

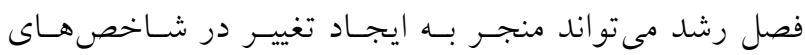

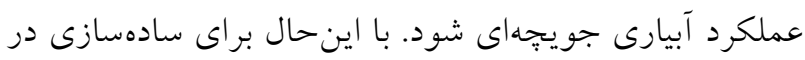

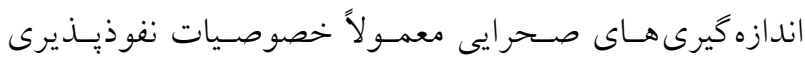

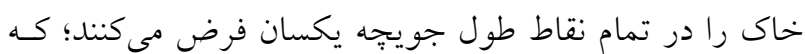




$$
\begin{aligned}
& \text { سياسگز ارى } \\
& \text { تحت تأثير قرار مىدهـــ. لــذا حجـم روانـاب توليـد شــده در }
\end{aligned}
$$

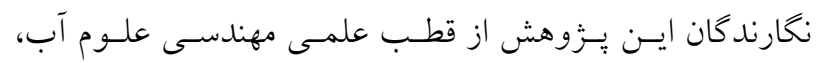

$$
\begin{aligned}
& \text { انتهاى فصل بيشتر از ابتداى فصل خواهد شد كه با بركرداندن } \\
& \text { دانشخاه شهيد جِمران اهواز كـه هزينـه انجـام يــروزه را متقبـل }
\end{aligned}
$$

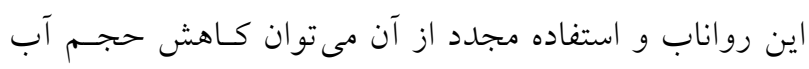

$$
\begin{aligned}
& \text { شدند؛ همجنين از مؤسسه تحقيقات و آموزش توسعه نيشـكر و } \\
& \text { نفوذ كرده را از طريق افزايش زمان آبيارى جبران كـرد. نتـايج } \\
& \text { صنايع جانبى خوزستان بهدليل همكارى در امور اجرايسى يسروزه } \\
& \text { نهايت سباس و امتنان را دارند. } \\
& \text { نشان داد؛ در صورت ثابت فرض كردن نقوذ در طول جويجنه. } \\
& \text { براى هر كدام از شاخص هاى ارزيابى TWR، DA }
\end{aligned}
$$

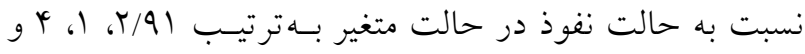

$$
\begin{aligned}
& \text { 1r/V9 }
\end{aligned}
$$

\section{منابع مورد استفاده}

1. Abdi, H. and L. J. Williams. 2010. Newman-Keults test and Tukey test. Encyclopedia of Research Design. Thousand Oaks. CA: Sage. 1-11.

2. Bavi A., S. Boroomand Nasab and A. A. Naseri. 2014. The effects of spatial variability of infiltration rate along a furrow on furrow irrigation efficiencies. Irrigation sciences and engineering (Scientific Journal of Agriculture) 37(2): 39-50. (In Farsi)

3. Childs, J. L., W. W. Wallender and J. W. Hopmans. 1993. Spatial and seasonal variation of furrowinfiltration. Journal of Irrigation and Drainage Engineering 119(1): 74-90.

4. Elliot, R. I. and D. E. Eisenhauer. 1983. Volume balance techniques for measuring infiltration in surface irrigation Chicago. Transaction of the American Society of Agricultural Engineers. III: 83-2520. (Presented at the1983 Winter Meeting of the ASAE Chicago III).

5. Elliot, R. L. and W. R. Walker. 1982. Field evaluation of furrow infiltration and advance functions. Transactions of the ASAE 25(2): 396-400.

6. Emdad, M. R., H. Shahabi-far and H. Fardad. 2006. Effect of temporal variability of infiltration on the management of furrow irrigation. Journal of Soil and Water Science 21(2): 319-326. (In Farsi).

7. Fernandez-Gomez, R., L. Mateos and J. V. Giraldez. 2004. Furrow irrigation erosion and management. Irrigation Science 23: 123-131.

8. Furman, A., A. W. Warrick, D. Zerihun and C. A. Sanchez. 2006. Modified Kostiakov infiltration function: Accounting for initial and boundary conditions. Journal of Irrigation and Drainage Engineering 132(6): 587-596.

9. Grassi, C. G. 1972. Infiltration characteristics of furrow irrigation in a heavy Soil. Wagenigen 72(7): 115-118.

10. Izadi, B., D. Studer and I. MC-Cann. 1991. Maximizing setwide furrow irrigation application efficiency under full irrigation strategy. Transaction of the ASAE 34(5): 2006-2014.

11. Jaynes, D. B. and D. J. Hunsaker. 1989. Spatial and temporal variability of water content and infiltration on a flood irrigated field. Transaction of the ASAE 32: 1229-1238.

12. Kanya, L. and R. J. Smith. 2006. Real-time prediction of soil infiltration characteristics for the management of furrow irrigation. Irrigation Science 25(1): 33-43.

13. Kazeroonian, S. M., F. Abbasi and H. Sedghi. 2017. Atatistical study of infiltration parameters variations of Kostiakov-Lewis equation in furrow irrigation during three farming seasons. Journal of Water and Soil Conservation 24(4): 83-101. (In Farsi)

14. Klute, A. 1986. Water retention: Laboratory methods. In: Klute, A. (Eds), Methods of Soil Analysis. Part 1. American Society of Agronomy 9: 635-622

15. Langat, R., R. Smith and S. R. Raine. 2008. Estimating the furrow infiltration characteristics from a single advance point. Irrigation Science 26(5): 367-374.

16. Li, Y., J. N. Tullberg and D. M. Freebrian. 2001. Traffic and residue cover effects on infiltration. Australian Journal of Soil Research 39(2): 239-247.

17. Maleki, A. 2004. Investigation of Seasonal and spatial variation of infiltration in Furrow irrigation in the southern Ahwaz sugar cane lands. Ph. D. dissertation, Shahid Chamran University of Ahwaz. (In Farsi)

18. Maroufpoor, E., A. Seyedzadeh and M. Behzadynasab. 2017. Investigation of the accuracy of Non-point infiltration measurement methods in designing of furrow irrigation system. Journal of Water and Soil Conservation 24(2): 257- 
271. (In Farsi).

19. Medina, J. and D. Martin. 1998. Infiltration model for furrow irrigation. Journal of Irrigation and Drainage Engineering 124(2): 73-80.

20. Merriam, J. L. and J. Keller. 1978. Farm irrigation system evaluation: A guide for management. Agricultural and Irrigation Engineering Department. Utah State University. Logan. Utah.

21. Mirzaee, S., A. A. Zolfaghari, M. Gorji, M. Dyck and S. Ghorbani Dashtaki. 2013. Evaluation of infiltration models with different numbers of fitting parameters in different soil texture classes. Archives of Agronomy and Soil Science 60(5): 681-693.

22. Mollaei, M., H. Bashari, M. Basiri and M. R. Mosaddeghi. 2015. Soil structural stability assessment using wetsieving method in selected rangeland sites in Isfahan province. Journal of Hydrology and Soil Science 18(4): 121133. (In Farsi).

23. Raine, R. and J. MC-Clymont. 1997. The development of guidelines for surface irrigation in areas with variable infiltration. Proceeding of Australian Society of Sugarcane Technologists.

24. Reddy, J. M. and W. Clyma. 1981. Optimal design of furrow irrigation systems. Transaction of the ASAE 24(3): 617-623.

25. Tabatabaei, S. H., H. Fardad, M. R. Neyshabory and A. Liaghat. 2004. Seasonal and spatial variation of furrow cross section. Journal of Agricultural Sciences and Natural Resources 11(2): 171-179. (In Farsi).

26. Wallender, W. W. 1986. Furrow model with spatially varying infiltration. Transaction of the ASAE 29(4): 10121016.

27. Wu, I. P. and T. Liang. 1970. Optimal design of furrow length of surface irrigation. Journal of Irrigation and Drainage, ASCE 96(3): 319-332.

28. Zapata, N. and E. Playan. 2000. Elevation and infiltration in a level basin. Irrigation Science 19(4): 155-164. 


\title{
The Analysis of the Indexes of Furrow Irrigation Efficiency Evaluation for the Condition of Uniform and Variable Infiltration
}

\author{
F. Haghnazari ${ }^{1}$, M. Ghanbarian Alavijeh ${ }^{2 *}$, A. Sheini Dashtegol ${ }^{3}$ and \\ S. Boroomand Nasab ${ }^{3}$
}

(Received: March 3-2020 ; Accepted: August 5-2020)

\begin{abstract}
Changes in soil infiltration cause changes in irrigation efficiencies; therefore, estimating it in calculating irrigation efficiencies provides a more accurate estimate of irrigation performance indicators. In a study conducted on ARC2-7 farm in Amirkabir agro-industry in the 2010-2011 crop year, during four irrigations; two furrows were selected in terms of uniform infiltration and variable infiltration with a length of 140 and a width of $1.83 \mathrm{~m}$. In the furrow assuming uniform infiltration two flume type II, at the beginning and end of it, were installed and the cumulative infiltration was determined by the volume balance method. The furrow with variable conditions was divided into four sections by installing five flumes. By examining the spatial variations of the mean cumulative infiltration, its value decreased from the first to the fourth section for the first irrigation by $15 \%$ and for the subsequent irrigations by $13 \%$. Temporal changes of cumulative infiltration decreased by 27 and $30 \%$ for the first and second sections and by $26 \%$ for the third and fourth sections. An 11\% increase in the average weight of the aggregate diameter and a 7\% decrease in bulk density indicate physical changes in the soil. Surface runoff losses increased from 8 to $18.77 \%$ in the furrow assuming uniform infiltration and from 10.91 to $19.77 \%$ in the furrow with variable infiltration, and application efficiency decreased by $6 \%$.
\end{abstract}

Keywords: Furrow irrigation, application efficiency, Permeability, infiltration variations

1. Irrigation and Drainage Department, College of Water and Soil, Zabol University, Zabol, Iran.

2. Water Engineering Department, College of Agriculture, Isfahan University of Technology, Iran.

3. Irrigation and Drainage Department, College of Water Sciences \& Engineering, Shahid Chamran University of Ahvaz, Ahvaz, Iran.

Corresponding author, Email: mahshid.ghanbarian@gmail.com 